\title{
Oikeus ja kohtuus
}

Häyry, Matti, Takala, Tuija \& Ahola-Launonen, Johanna (toim.) (2018). Oikeudenmukaisuuden ongelma. Gaudeamus. 343 sivua.

KUN OIKEUDENMUKAISUUTTA ei ole helppo määritellä, voi olla helpompaa määritellä, mitä se ei ole. Ensinnäkään oikeudenmukaisuus ei ole yhtä kuin moraali, koska moraali liitetään usein yksilöiden toimintaan ja oikeudenmukaisuus instituutioihin. Toiseksi se ei ole lain noudattamista, koska lait voidaan kokea epäoikeudenmukaisiksi, ja niiden muuttamiseksi kerätään kansalaisadresseja. Italialaishistorioitsija Paolo Prodin mukaan oikeudenmukaisuus on muuttunut omantunnon asiaksi, ja yleisesti tunnustetun oikeusetiikan puuttuessa olemme neuvottomia eutanasian tai luonnonsuojelun kaltaisissa kysymyksissä.

Kolmanneksi oikeudenmukaisuus ei ole yhtä kuin armollisuus tai inhimillisyys, ja se voi olla joskus näille vastakkainenkin. Tasapainoilu oikeudenmukaisuuden ylevien periaatteiden, lain tai normin noudattamisen sekä moraalisesti oikeaksi koetun välillä voi olla melkoista akrobatiaa.

Oikeudenmukaisuutta voi tarkastella yksilön, ryhmän, sukupolven tai koko yhteiskunnan näkökulmasta. Sillä voi viitata ainakin tasa-arvoisuuteen, yhdenvertaisuuteen, kuten ihmisarvoon ja yhtäläisen kohteluun, tasapuolisuuteen sekä päätöksenteon yhteydessä kaikkien asianosaisten huomioon ottamiseen. Filosofi Jürgen Habermasia mukaillen oi- keudenmukaisuudesta voidaan puhua teknishallinnollisin, tulkinnallisin tai emansipatorisin intressein.

Tutkijakolmikon toimittamassa 22 artikkelin kokoelmassa oikeudenmukaisuutta tarkastellaan historiallisesta, filosofisesta, psykologisesta sekä sosiaali- ja oikeustieteellisestä näkökulmasta. Teoksen viidessä luvussa syvennytään eri teemoihin - ryhmien vastakkaisuudesta ja kohtaamisesta oikeudenmukaisuuden historialliseen taustaan.

\section{PROFEETTOJEN PALAUTE}

Vanhan testamentin profeetat Jesaja ja Aamos moittivat 700-luvulla ennen ajanlaskun alkua aikalaisiaan ankarin sanoin muun muassa koron ja lahjusten ottamisesta sekä velallisen hädänalaisen aseman hyväksi käyttämisestä. Syytöksiä saivat rikkaat, jotka "liittävät talon taloon ja pellon peltoon” eli keräsivät maaomaisuutta. Profeettojen moitteen saivat myös väärät asenteet, jotka johtivat vääriin tekoihin, kuten ahneuteen tai viisauteen "omissa silmissään".

Filosofi Aristoteles (384-322 eaa.) kirjoittaa Nikomakhoksen etiikassa, että oikeudenmukaisuus kattaa kaikki hyveet ja edistää myös muiden hyvää. Oikeudenmukaisuutta parempi periaate voisi hänen mukaansa olla koh-

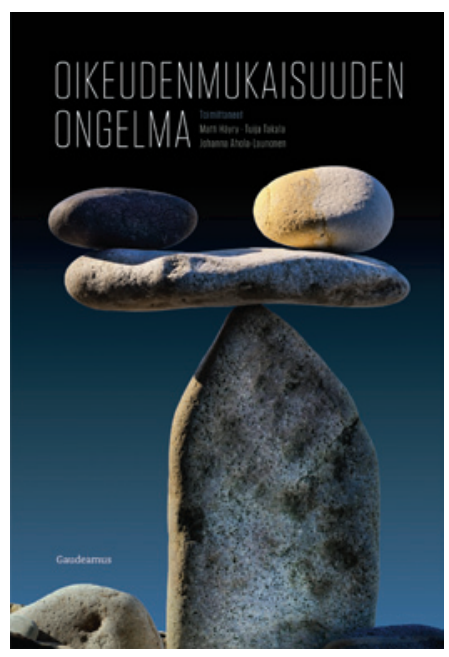

tuudenmukaisuus, tilanteen erityispiirteiden huomioon ottaminen. Oikeuksien jakautumiseen liittyvä distributiivinen oikeudenmukaisuus merkitsee Aristoteleella oikeuksien jakamista "geometrisesti", samassa suhteessa kuin ansio. Esimerkiksi valtion rahastosta tuetaan henkilöä samassa suhteessa kuin hän on siihen sijoittanut. Vääryyttä korjaava retributiivinen oikeudenmukaisuus tarkoittaa menetyksen korvaamista "aritmeettisesti", samansuuruisena kuin menetys on ollut.

\section{ENSISIJAINEN HYVÄ}

Oikeudenmukaisuus nousi viime vuosikymmeninä poliittisen filosofian keskeiseksi kysymykseksi filosofi John Rawlsin oikeudenmukaisuusteorian myötä. Oikeudenmukaisuuden periaatteet valitaan kuvitteellisessa alkutilanteessa, jossa osapuolet vetäytyvät tietämättömyyden verhon taakse siten, että he eivät voi ajaa omaa 
etuaan vaan kaikkien kannalta edullisia periaatteita. Ratkaisujen on tuotettava suurin mahdollinen hyöty taloudellisesti ja sosiaalisesti heikoimmassa asemassa oleville. Tuloerot voi oikeuttaa, kun niistä hyötyy myös heikoimmassa asemassa oleva ryhmä.

Oikeudenmukaisen jaon kohteena ovat ensisijaiset hyvät (primary goods), kuten perusvapaudet ja -oikeudet, mahdollisuudet, tulot ja varallisuus, sekä itsekunnioituksen sosiaalinen perusta. Ne ovat Rawlsin mukaan hyvän elämän voimavaroja riippumatta siitä, mitä kukin pitää hyvänä elämänä.

Taloustieteilijä Amartya Senin ja filosofi Martha Nussbaumin mukaan resurssien sijasta olisi tärkeämpää tarkastella todellisia mahdollisuuksia eli toimintakyvyn jakautumista. Toimintakyvyt (capabilities) merkitsevät hyvinvoinnin ja oikeudenmukaisuuden minimiä, muun muassa terveyttä ja ruumiillista koskemattomuutta, joihin kaikilla tulee olla mahdollisuus. Minkä tahansa toimintakyvyn vastentahtoinen puuttuminen on sosiaalinen haitta, jonka poistaminen on yhteiskunnan vastuulla.

\section{OIKEUDENMUKAISUUDEN TOIVE SUOMALAISUUDEN OSANA}

Yhteiskunnallista oikeudenmukaisuutta voi tarkastella joko kysymällä oman yhteiskuntamme oikeudenmukaisuudesta tai pohtimalla, millainen yhteiskunta olisi oikeudenmukaisin. Oletukset "meistä" ja "muista" vaikuttavat käsityksiin oikeudenmukaisimmasta toimintatavasta tai yhteiskunnasta. Jos työttömiä ja köyhiä pidetään laiskoina ja kunniattomina, he ovat tilanteestaan itse vastuussa eivätkä ansaitse yhteiskunnan tukea.

Mediassa tämäntyyppinen painotus on tutkimuksen mukaan 25 viime vuoden aikana lisääntynyt, mutta mielipide heijastelee vain pienen äänekkään ryhmän käsityksiä. Suomalaisista peräti 85 prosenttia pitää hyvinvointivaltiota erittäin tai melko tärkeänä identiteettinsä osana. Se on tutkimuksen mukaan tärkeämpi osa identiteettiämme kuin suomalainen kulttuuri, kotimainen ruoka tai talvisota.

Jatkuva, suhdanteista riippumaton talouskuri (age of austerity) nävertää hyvinvointivaltion edellytyksiä. Luottamus ihmisten ja instituutioiden oikeudenmukaisuuteen on yhä suuri, mutta eriarvoisuus lisääntyy nopeasti.

\section{EPÄOIKEUDENMUKAISUUS}

\section{SAIRASTUTTAA}

Työpaikoilla oikeuden- tai epäoikeudenmukaisuuden kokemukset herättävät voimakkaita myönteisiä tai vastaavasti kielteisiä tunteita. Niillä, jotka kokevat johtamisen epäoikeudenmukaiseksi on 15-35 prosenttia suurempi sairausloman riski kuin niillä, jotka kokevat johtamisen oikeudenmukaiseksi. Kouluissa, joiden henkilöstö pitää päätöksenteon periaatteita epäoikeudenmukaisina, oppilaat ovat muita tyytymättömämpiä koulunkäyntiin. Oppilaitoksen henkilöstön huonot kokemukset kohtelun oikeudenmukaisuudesta ovat myös yhteydessä oppilaiden heikompiin arvosanoihin sekä psykosomaattisiin ja masennusoireisiin.

Oikeudenmukaisuuden ongelma on huolellisesti toimitettu ja moneen suuntaan ulottuva kokonaisuus aihealueestaan. Historiasta kiinnostunut lukija olisi mielellään nähnyt kirjan ansiokkaan historiaosuuden jo alussa, tuomassa jäsennystä ajankohtaiseen keskusteluun. Oikeudenmukaista johtamista käsitellään, mutta teos olisi voinut lisäksi sisältää artikkelin priorisointiin liittyvistä oikeudenmukaisuuskäsityksistä auttamis- ja ihmissuhdeammateissa.

\section{JUSSI ONNISMAA}

FT, dosentti, tietokirjailija

Werka kehitys Oy 